\title{
Correction to: Influence of Cystic Fibrosis-Related Diabetes on Mental Health in Adults: A Single-Center Study
}

\author{
Michelle Hjelm ${ }^{1,5}$ - Dmitry Tumin ${ }^{2} \cdot$ Christopher J. Nemastil $^{3} \cdot$ Ann E. Salvator ${ }^{4}$ - Don Hayes Jr. ${ }^{1,5}$
}

Accepted: 21 November 2020 / Published online: 24 November 2020

(c) Springer Science+Business Media, LLC, part of Springer Nature 2020

\section{Correction to: Lung}

https://doi.org/10.1007/s00408-020-00396-5

The original version of this article unfortunately contained a mistake in one of the co-author name Prof. Don Hayes Jr. During production process, "Jr." was missed to add after the author name. The author name is corrected with this correction.
The original article can be found online at https://doi.org/10.1007/ s00408-020-00396-5.

Michelle Hjelm

michelle.hjelm@cchmc.org

Dmitry Tumin

tumind18@ecu.edu

Christopher J. Nemastil

CJ.Nemastil@nationwidechildrens.org

Ann E. Salvator

AnnSalvator@yahoo.com

Don Hayes Jr.

Don.Hayes@cchmc.org

1 Division of Pulmonary Medicine, Department of Pediatrics, Cincinnati Children's Hospital Medical Center, University
The original article has been corrected.

Publisher's Note Springer Nature remains neutral with regard to jurisdictional claims in published maps and institutional affiliations. 